\title{
ホウ酸塩を含むメラミン樹脂からのB/C/N 材料の調製とそのキャパシタ特性
}

\section{Preparation of $\mathrm{B} / \mathrm{C} / \mathrm{N}$ materials from melamine resin with borate and their capacitive performance}

\section{新井保彦・衣本太郎・津村朋樹・豊田昌宏*}

Yasuhiko Arai, Taro Kinumoto, Tomoki Tsumura and Masahiro Toyoda*

\begin{abstract}
Melamine-formaldehyde resin containing boron was prepared from boric acid, melamine and formaldehyde. B/C/N materials were prepared through carbonization of the boron-containing resin at $800-1000{ }^{\circ} \mathrm{C}$ in an inert atmosphere. A high nitrogen content ( $\mathrm{N} / \mathrm{C}$ ratio) was achieved through the formation of $\mathrm{B}-\mathrm{N}$ bonding due to the added boron. The highest N/C ratio of 0.24 was observed even at a high heat-treatment temperature of $1000{ }^{\circ} \mathrm{C}$. Its electric double-layer capacitance (EDLC) was as high as $500 \mathrm{~F} / \mathrm{g}$ (at a constant current $=100 \mathrm{~mA} / \mathrm{g}$ ), although its specific surface area was not huge compared to that of activated carbon. From the standpoint of specific capacitance per unit surface area, it was clearly shown that nitrogen content greatly contributes to the EDLC performance.
\end{abstract}

KEYWORDS : Pyrolysis, X-ray photoelectron spectroscopy, Electrochemical properties, Capacitor

\section{1. 緒 言}

電気二重層キャパシタ（EDLC）は，電極-電解液界面に電 荷を蓄える電極材料である ${ }^{1)}$ 。その容量は電極面積と比例関係 にあることから活性炭などの高比表面積の炭素材料が電極に用 いられる。しかしながら比表面積の増加に伴う細孔容積の増加 から容積当たりの容量は限界に達しており ${ }^{2)}$, 電極面積の増加 によるエネルギー密度の向上は限界がある。最近, 水系電解液 中で窒素を含む炭素材料でその比表面積以上に高容量を示すこ とが報告され ${ }^{3)-5}$ ， その高容量化は，窒素含有表面官能基によ るレドックス容量の寄与，極性の増加による濡れ性の向上の関 与が報告されている ${ }^{6}$ 。また，窒素が炭素材料にドープされる と炭素六角網面内に電荷の偏りが生じ, 構造的な歪みが生じる ことも報告されている7),8)。この六角網面内での電荷の偏り は，ホウ素をドープした場合により大きくなることが報告され て抢り ${ }^{9)}$, 構造末端のホウ素原子は, 濡机性にも影響すると報 告されている ${ }^{10)}$ 。これらのことからホウ素㧍よび窒素をドー プした炭素材料をEDLC電極に用いることで, 比表面積に比例 しないこれまでにない高容量を示す新しい炭素電極材料が期待 され，金野らは，窒素，炭素源にポリアクリルアミドを用いて ホウ酸を添加した $\mathrm{B} / \mathrm{C} / \mathrm{N}$ 材料を調製し $1 \mathrm{~mol} / \mathrm{dm}^{3} \mathrm{H}_{2} \mathrm{SO}_{4}$ 電解液 中, 走查速度 $2 \mathrm{mV} / \mathrm{s}$ で $300 \mathrm{~F} / \mathrm{g}\left(0.8 \mathrm{~F} / \mathrm{m}^{2}\right)$ の高容量を示すこと を報告している ${ }^{11)}$ 。

BN結合を含む炭素材料の形成として，六方晶窒化ホウ素は
メラミンホウ酸塩の熱分解物から得られることが知られてお り，窒素含有率の高いメラミンとホウ酸を出発原料として用い ることで $\mathrm{BN}$ 結合の形成が期待される。しかしながら，メラミ ン単体では熱分解物を得ることは難しい。そこで本研究では, メラミン樹脂前駆体とホウ酸混合物から合成した樹脂を熱処理 により炭素化物を調製し，それをキャパシタ電極として評価を 試みた。

\section{2. 実験方法}

ホウ酸 $\left(\mathrm{H}_{3} \mathrm{BO}_{3}\right)$ は，メラミン $\left(\mathrm{C}_{3} \mathrm{H}_{6} \mathrm{~N}_{6}\right)$ に対して $0.1 \mathrm{~mol}$ 当 量となるようにメラミンとともに水に分散させ，懸濁水溶液と し $60{ }^{\circ} \mathrm{C}$ で摚拌した。ホルムアルデヒド $\left(\mathrm{CH}_{2} \mathrm{O}\right)$ をメラミンに 対して $1.3 〜 2.7 \mathrm{~mol}$ となるようにその懸濁水溶液に添加した後 30 分間還流を行い，透明なメチロールメラミンが生成すること を確認した。そこに重縮合を促進するために $1 \mathrm{~mol} / \mathrm{dm}^{3}$ 塩酸を $\mathrm{pH} 4$ になるよう加え, $95^{\circ} \mathrm{C} て ゙ 1$ 時間保持し白色沈殿物を得た。 白色沈殿物を含む液体を $50{ }^{\circ} \mathrm{C}$ で乾燥を行い，ホウ素含有メラ ミン樹脂（MFB resin）を得た。また比較として同様の手法に よりホウ素を含まないメラミン樹脂（MF resin）も調製した。 得られた各樹脂を電気管状炉を用い窒素雲囲気中 $800{ }^{\circ} \mathrm{C}$ ない し $1000{ }^{\circ} \mathrm{C} て ゙ 1$ 時間焼成することにより炭素化した。得られた 炭素化物の副生成物である三酸化二ホウ素 $\left(\mathrm{B}_{2} \mathrm{O}_{3}\right)$ は煮沸洗浄 により除去し, $\mathrm{B} / \mathrm{C} / \mathrm{N}$ 材料とした。以下, $\mathrm{B} / \mathrm{C} / \mathrm{N}$ 材料は, 出発原 料樹脂, ホルムアルデヒド /メラミン比 ( $\mathrm{F} / \mathrm{M}$ 比), 熱処理温度

* Corresponding Author, E-mail: toyoda22@oita-u.ac.jp

(平成23年7月13日受理, 平成23年10月18日採択) 大分大学工学部応用化学科：干870-1192 大分市旦野原700

Department of Applied Chemistry, Faculty of Engineering, Oita University: 700 Dannoharu, Oita 870-1192, Japan 
の順にMFB1.3-1000のように表す。

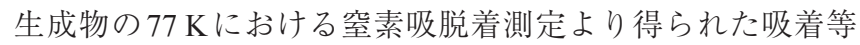
温線より, 比表面積 $\left(\alpha_{\mathrm{s}}\right.$-SPE法), 細孔容積 (BJH 法) の算出を 行った。 $\mathrm{C}, \mathrm{B}, \mathrm{N}, \mathrm{O}$ の組成比および結合状態は，インジウム箔 上のサンプルをX 線光電子分光法 (XPS, $\mathrm{Al} K_{\alpha}, 100 \mathrm{~W}$ ) にて測 定し，いずれのサンプルにおいても C1sに大きな差異がなかっ たことから C-C $=284.8 \mathrm{eV}$ とて帯電補正を行い検討した。

キャパシタ特性は, $\mathrm{B} / \mathrm{C} / \mathrm{N}$ 材料に導電材（カーボンブラック） を $10 \mathrm{wt} \%$ 添加して, 白金板に圧着したものを作用極とし, 対極 に白金板，参照極に $\mathrm{Ag} \mid \mathrm{AgCl}$ ，電解液に $40 \mathrm{wt} \% \mathrm{H}_{2} \mathrm{SO}_{4}$ を用いた 三極セルでサイクリックボルタンメトリー $(\mathrm{CV}$, 走査速度 : $1 \mathrm{mV} / \mathrm{s}$, 電位範囲 : 0 $1 \mathrm{~V})$, 定電流法による容量測定 $(\mathrm{C} / \mathrm{D}$, 電流值 : $100 \mathrm{~mA} / \mathrm{g}$, 電位範囲 : 0 $1 \mathrm{~V} v \mathrm{~s} . \mathrm{Ag} \mid \mathrm{AgCl})$ を行い, 時 間当たりの電位の変化量から EDLC容量を算出した。

\section{3. 結果と考察}

Table 1 にPS 測定より得られた B, C, N, Oの組成比および $\mathrm{N} / \mathrm{C}$ 比, ガス吸着測定より得られた比表面積 (SSA), ミクロ孔 容積 $\left(V_{\text {mic }}\right)$, メソ孔容積 $\left(V_{\text {meso }}\right)$, 定電流測定より算出した容 量を示す。ホウ酸を添加していないMF樹脂を出発原料とした 材料では, $800{ }^{\circ} \mathrm{C}$ 炭素化時には高い $\mathrm{N} / \mathrm{C}$ 比を示すものの, $1000{ }^{\circ} \mathrm{C}$ 炭素化時において, N/C 比が約 0.05 と急激な低下を示し た。これは, そのほかの窒素含有樹脂を用いた熱分解炭素の調 製でも認められているもので5), 熱処理による炭素網面構造の 発達に伴って窒素サイトの減少に起因すると推察されている。 一方，ホウ酸を添加したMFB樹脂を出発原料とした材料では, $1000{ }^{\circ} \mathrm{C}$ 炭素化時においても $\mathrm{N} / \mathrm{C}$ 比の低下は認められず 0.09 0.24 と高い值を維持していた。Fig. 1 に各F/M比で調製した MF，MFB樹脂を $1000{ }^{\circ} \mathrm{C} て ゙$ 炭素化した材料のN1sのXPS スペク トルを示す。各 $\mathrm{F} / \mathrm{M}$ 比で調製した MFB樹脂を $1000{ }^{\circ} \mathrm{C} て ゙$ 炭素化 した材料ではピリジン型窒素 $(398.5 \pm 0.2 \mathrm{eV})$, 四級窒素 $(401.2 \pm 0.2 \mathrm{eV})$ 以外に MF 樹脂を出発原料とした材料では認 められない399.3 eV 付近の新たなピークが認められた。金野ら は，ポリイミドフィルムに dihydroxyphenylboraneを添加した系
で $800{ }^{\circ} \mathrm{C}$ 以上の炭素化により $\mathrm{BN}$ 結合 $(398.8 \pm 0.2 \mathrm{eV})$ の形成 を報告 ${ }^{12)}$ していることから，このピークは，BN結合による ピークと推察され， $\mathrm{BN}$ 結合が新たに形成されたことにより $1000{ }^{\circ} \mathrm{C}$ 炭素化においても窒素サイトが減少せず，高い $\mathrm{N} / \mathrm{C}$ 比 を維持したと考えられた。また，MFB樹脂を $1000{ }^{\circ} \mathrm{C} て ゙$ 炭素化 した材料のホウ素の含有率は, F/M比が小さいほど大きかっ た。メラミンは, ホウ酸とジボランの塩を形成することが知ら れており，F/M比が小さいほどメチロール化による立体障害が 小さくメラミン近傍にホウ酸が塩として樹脂中に取り込まれ, 結果として多くのBN結合が形成されたと考えられた。Fig. 1 に認められるようにMFB樹脂由来の材料では，四級窒素の形 成が著しく低下しており，とりわけF/M比が小さな MFB1.3で 顕著であった。これはホウ素含有率と反比例しており，メラミ ン近傍で BN結合の形成が進むことにより四級窒素の形成が抑 制されたと考えられた。一方，SSAは，そのほとんどが出発樹 脂由来であり，炭素化温度が高くなるにつれて減少することが 認められたが，ホウ酸添加による違いは認められなかった。

Fig. 2 にF/M比が1.3の MF1.3-800, MF1.3-1000, MFB1.3-1000

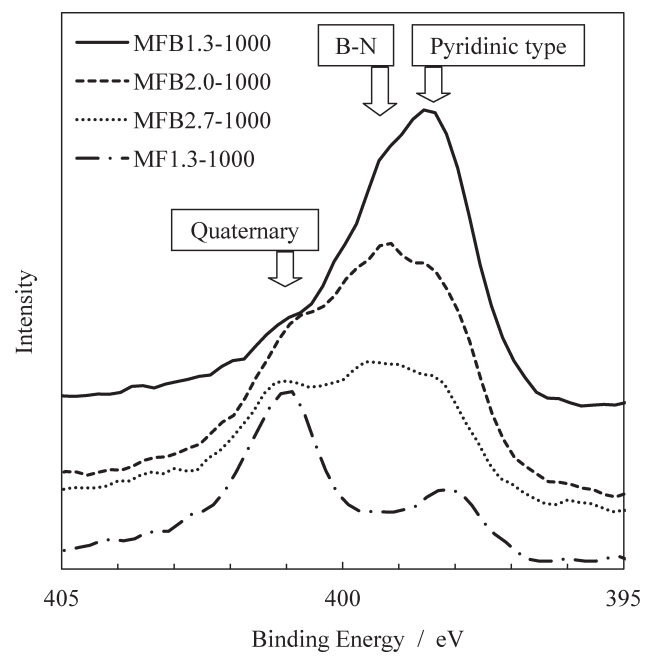

Fig. 1 XPS spectrum of N1s on MFB and MF resin carbonized at $1000{ }^{\circ} \mathrm{C}$.

Table 1 Chemical composition from XPS measurement, surface characteristics, capacitances of carbonized MFB and MF resin.

\begin{tabular}{|c|c|c|c|c|c|c|c|c|c|c|}
\hline \multirow{2}{*}{ Sample } & \multirow{2}{*}{$\begin{array}{c}\mathrm{C} 1 \mathrm{~s} \\
{[\text { atom } \%]}\end{array}$} & \multirow{2}{*}{$\begin{array}{c}\mathrm{N} 1 \mathrm{~s} \\
{[\text { atom \%] }}\end{array}$} & \multirow{2}{*}{$\begin{array}{c}\mathrm{O} 1 \mathrm{~s} \\
{[\operatorname{atom} \%]}\end{array}$} & \multirow{2}{*}{$\begin{array}{c}\mathrm{B} 1 \mathrm{~s} \\
{[\text { atom } \%]}\end{array}$} & \multirow{2}{*}{$\mathrm{N} / \mathrm{C}$} & \multirow{2}{*}{$\begin{array}{l}\text { S.S.A. } \\
{\left[\mathrm{m}^{2} / \mathrm{g}\right]}\end{array}$} & \multirow{2}{*}{$\begin{array}{c}V_{\mathrm{mic}} \\
{[\mathrm{ml} / \mathrm{g}]}\end{array}$} & \multirow{2}{*}{$\begin{array}{c}V_{\text {meso }} \\
{[\mathrm{ml} / \mathrm{g}]}\end{array}$} & \multicolumn{2}{|c|}{ Capacitance } \\
\hline & & & & & & & & & {$[\mathrm{F} / \mathrm{g}]$} & {$\left[\mathrm{F} / \mathrm{m}^{2}\right]$} \\
\hline MF1.3-800 & 75.3 & 22.5 & 2.2 & - & 0.30 & 280 & 0.13 & 0.40 & 308 & 1.10 \\
\hline MF2.0-800 & 74.1 & 19.5 & 6.4 & - & 0.26 & 330 & 0.15 & 0.23 & 305 & 0.92 \\
\hline MF2.7-800 & 80.1 & 16.8 & 3.1 & - & 0.21 & 560 & 0.25 & 0.13 & 300 & 0.54 \\
\hline MF1.3-1000 & 92.0 & 5.6 & 2.4 & - & 0.06 & 140 & 0.08 & 0.34 & 79 & 0.56 \\
\hline MF2.0-1000 & 92.4 & 4.8 & 2.8 & - & 0.05 & 300 & 0.16 & 0.20 & 114 & 0.38 \\
\hline MF2.7-1000 & 90.3 & 4.7 & 5.0 & - & 0.05 & 530 & 0.25 & 0.21 & 145 & 0.27 \\
\hline MFB1.3-800 & 70.1 & 20.9 & 6.1 & 2.8 & 0.30 & 510 & 0.26 & 0.23 & 451 & 0.88 \\
\hline MFB2.0-800 & 64.9 & 21.2 & 11.7 & 2.2 & 0.33 & 350 & 0.16 & 0.12 & 415 & 1.19 \\
\hline MFB2.7-800 & 69.0 & 21.8 & 7.7 & 1.5 & 0.32 & 320 & 0.16 & 0.15 & 357 & 1.12 \\
\hline MFB1.3-1000 & 66.0 & 15.6 & 8.9 & 9.4 & 0.24 & 460 & 0.26 & 0.54 & 497 & 1.08 \\
\hline MFB2.0-1000 & 78.5 & 11.3 & 6.1 & 4.2 & 0.14 & 300 & 0.16 & 0.34 & 215 & 0.72 \\
\hline MFB2.7-1000 & 84.2 & 7.5 & 5.6 & 2.8 & 0.09 & 600 & 0.29 & 0.16 & 318 & 0.53 \\
\hline
\end{tabular}




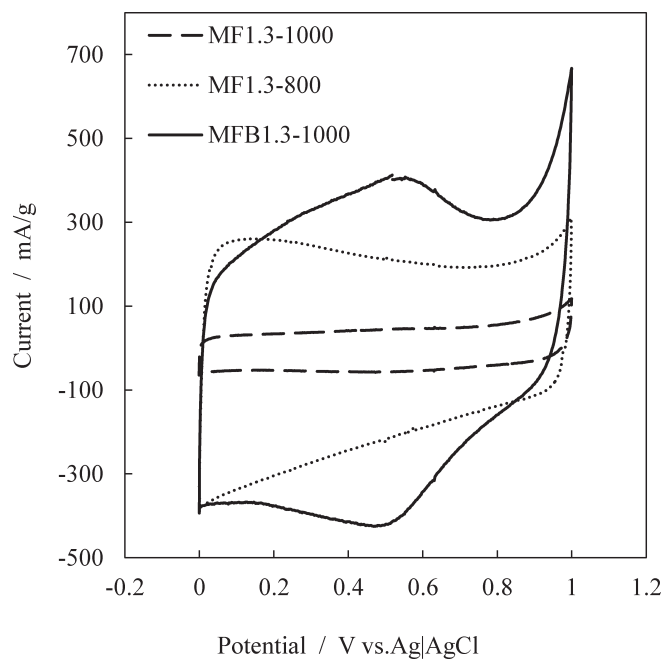

Fig. 2 Cyclic voltamograms of carbonized MF1.3 and MFB1.3 resin.

のCV特性を示す。MF1.3-800では, 低電位側で容量が増加する 窒素含有炭素に特徴的なヒステリシスが認められたが,MF1.31000 では，高電位側と低電位側で差異のない矩形を示した。一 方，MFB1.3-1000では，0.4 0.6 Vの電位領域に含酸素官能基と プロトンとの反応に起因する redox ピークが認められるヒステ リシスを示し，F/M比 2.0 および 2.7 においても同様の結果を示 した。重量当たりの容量で比較すると， $800{ }^{\circ} \mathrm{C}$ 炭素化では，い ずれも高い $\mathrm{N} / \mathrm{C}$ 比と $300 \mathrm{~F} / \mathrm{g}$ 以上の高容量を示し, MFB1.3-800 で $451 \mathrm{~F} / \mathrm{g}$ も高容量を示した。 $1000{ }^{\circ} \mathrm{C}$ 炭素化では，ホウ酸無 添加で $\mathrm{N} / \mathrm{C}$ 比が減少し, SSA ながらも，容量は大きく減少した。MFB樹脂由来の材料では， F/M比によりN/C比に違いが現れ，MFB1.3-1000では，N/C= $0.24, \mathrm{SSA}=460 \mathrm{~m}^{2} / \mathrm{g}$ で $500 \mathrm{~F} / \mathrm{g}$ 近い值を示したが, MFB2.71000 では, $\mathrm{SSA}=600 \mathrm{~m}^{2} / \mathrm{g}$ と MFB1.3-1000よりも高SSAを示し ながらも， N/Cが 0.09 と減少し，それにより容量も $318 \mathrm{~F} / \mathrm{g}$ に どまった。以上の結果より容量に大きく寄与している要因の一 つにN/C比が考えられ，N/C 比に対して単位面積当たりの容量 をプロットした図をFig. 3 に示す。 $1000{ }^{\circ} \mathrm{C} て ゙$ 炭素化した MF 樹 脂由来の材料では，小さい SSA と低いN/Cの為に窒素に起因す る容量以外の寄与が見受けられるが，それら以外の窒素を含む 材料を電極に用いたとき，Fig. 2 のMFB1.3-1000に認められる ような含酸素官能基とプロトンとの反応に起因する疑似容量を 含んではいるが，二重層容量分と比較して小さいためにプロッ トへの影響が小さいと考えられることから，N/C 比と単位面積 当たりの容量の間に相関が認められ，電極材中の N/C 比が容量 に大きく寄与していると推察された。一方，B/C比と単位面積 当たりの容量の相関は， $\mathrm{B} / \mathrm{C}$ 比の振り幅が小さいことがあるも のの明確には認められなかった。しかしながら，ホウ酸を添加 することにより $1000{ }^{\circ} \mathrm{C}$ 以上の炭素化においても高 $\mathrm{N} / \mathrm{C}$ 比を維 持でき，それにより高容量を発現できることが明らかとなっ た。

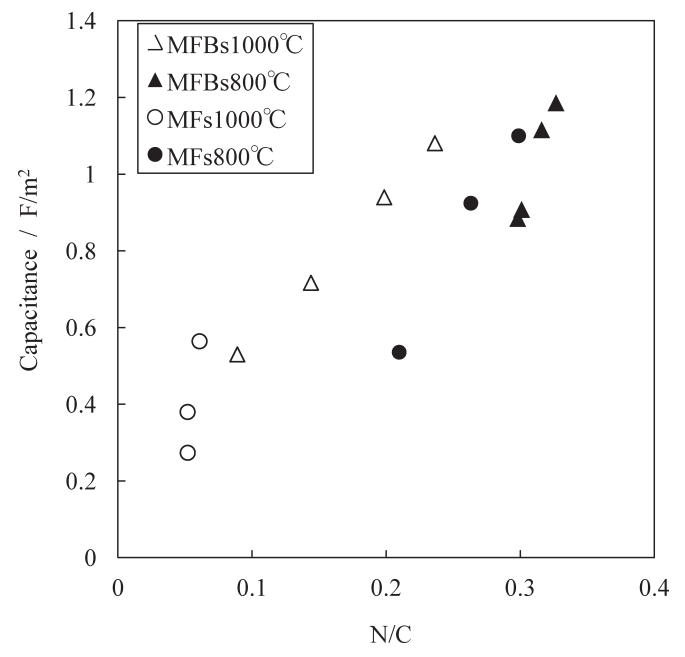

Fig. 3 The capacitances unit per SSA plots as function of the N/C for carbonized MFB and MF resin.

\section{4. まとめ}

メラミン樹脂前駆体とホウ酸混合物から合成した樹脂を窒素 気流中 $800 \sim 1000{ }^{\circ} \mathrm{C}$ で熱分解を行い $\mathrm{B} / \mathrm{C} / \mathrm{N}$ 材料を調製し，それ を電極として用いてキャパシタ特性について評価した結果，以 下のような知見が得られた。

1）ホウ素を添加することで，窒素の脱離が生じる $800{ }^{\circ} \mathrm{C}$ 以上 の焼成においても BN 結合を生成することで窒素の脱離を 抑制し， $1000{ }^{\circ} \mathrm{C}$ 焼成時においても $\mathrm{N} / \mathrm{C}$ 比が $0.09 \sim 0.24$ と高 い窒素含有率を示した。

2）窒素含有率の高い電極材を用いた場合には $500 \mathrm{~F} / \mathrm{g}$ （電流密 度； $100 \mathrm{~mA} / \mathrm{g}$ ）もの高容量を示し，とりわけ面積当たりの 比容量は， N/C 比に伴って増加するという関係が明らかと なった。

\section{謝 辞}

本研究の一部は, NEDO「ナノテク・先端部材実用化研究開 発」の助成を受けて行われました。

\section{文 献}

1) T. Morimoto, TANSO 2004 [No. 214] 202-209 [in Japanese].

2) T. Morimoto, TANSO 1999 [No. 189] 188-196 [in Japanese].

3) D. Hulicova, J. Yamashita, Y. Soneda, H. Hatori and M. Kodama, Chem. Mater. 17 (2005) 1241-1247.

4) M. Kodama, J. Yamashita, Y. Soneda, H. Hatori and K. Kamegawa, Carbon 45 (2007) 1105-1107.

5) S. Shiraishi and H. Mamyouda, TANSO 2008 [No. 232] 61-66 [in Japanese].

6) Y. Yamada, O. Tanaike and S. Shiraishi, TANSO 2004 [No. 215] 285-294 [in Japanese].

7) H. Konno, T. Nakahashi and M. Inagaki, Carbon 35 (1997) 669-674.

8) M. Inagaki, H. Tachikawa, T. Nakahashi, H. Konno and Y. Hishiyama, Carbon 36 (1998) 1021-1025.

9) H. Konno, K. Shiba, H. Tachikawa, T. Nakahashi, H. Oka and M. Inagaki, Synth. Met. 125 (2002) 189-196. 
10) T. Ito, M. Ushiro, K. Fushimi, K. Azumi and H. Konno, TANSO 2009 [No. 239] 156-161 [in Japanese].

11) H. Konno, T. Ito, M. Ushiro, K. Fushimi and K. Azumi, J. Power Sources
195 (2010) 1739-1746.

12) H. Konno, H. Oka, K. Shiba, H. Tachikawa and M. Inagaki, Carbon 37 (1999) 887-895. 